\title{
Continuity and Changes in Gandang Sarunai's Music Performance in Alam Surambi Sungai Pagu Society's Socio- Cultural Activities, South Solok Regency, West Sumatra
}

\author{
Marzam $^{1}$, Esy Maestro ${ }^{2}$ \\ ${ }^{1}$ The Lecturer of Arts, Drama, Dance and Music (Sendratasik) Department, Languages and Arts Faculty, \\ Universitas Negeri Padang \\ Prof. Dr. Hamka Air Tawar - Padang, West Sumatera. \\ ${ }^{2}$ Lecturer at Music Education Department, Languages and Arts Faculty, Universitas Negeri Padang \\ Prof. Dr. Hamka Air Tawar - Padang, West Sumatera. \\ marzam1962@fbs.unp.ac.id, esymaestro@fbs.unp.ac.id
}

*Corresponding Author

Received: day month 201x, Revised: day month 201x, Accepted: day month 201x

Published online: day month 201x

\begin{abstract}
This article discusses the continuity and change of gandang sarunai music performances in socio-cultural activities of the Alam Surambi Sungai Pagu community, South Solok, West Sumatra. The data were derived from the results of research compiled based on qualitative methods, utilizing literature study techniques, observation, interviews, and documentation techniques. The results of the study show that there has been a change in the performance of gandang sarunai music both in terms of venue and in terms of musical aspects of gandang sarunai nowadays. While the continuity of music is maintained, even when compared to the performances of gandang sarunai music during the time of Raja Alam of Surambi Sungai Pagu led the region administratively; gandang sarunai music has been used by all levels of society in their various socio-cultural activities nowadays. In the past, gandang sarunai music was only shown by and for the King's family. Nowadays, gandang sarunai music is used not only in the royal family's environment. Most people have also used gandang sarunai music in their various socio-cultural activities.
\end{abstract}

Keywords: performances, gandang sarunai music, continuity, change

\section{Introduction}

Alam Surambi Sungai Pagu, known as the Sungai Pagu Kingdom, is the Ikua Darek of the Minangkabau Kingdom in Pagaruyung. Several historical heritages can still be traced and interesting to be further researched, such as the presence of Puti Sigintir Palace, Tuangku Rajo Malenggang Palace and Rajo Putiah in Pasir Talang, and Tuanku Rajo Bagindo Palace in Balun. Historical relics during the early days of Islam in Minangkabau were Kurang Aso 60 Mosque in Pasir Talang and the Masjid Raya and surau Menara in Koto Baru. With the uniqueness of these historical relics, the former of Alam Surambi Sungai Pagu Kingdom will now be made as a world cultural heritage [1] Retrieved March 23, 2016.

During the reign of the kings, all kinds of traditional arts lived in sustaining the existence of social and cultural activities. Especially for gandang sarunai art, it was the art of kings which was only served at certain times, for example, when there was an event of death in the royal family, birth events in the royal family, a bathing ceremony for children in the royal family, a royal family wedding 
ceremony, a ceremony for the inauguration of a new king, as well as a ceremony to welcome the king's guests. [2] See also Maestro Esy; Marzam [3].

Nowadays, Alam Surambi Sungai Pagu as a cultural area is within the administrative area of South Solok Regency which is one of the new autonomous regions in Indonesia based on Law No. $38 / 2003$ and is effective from January 7, 2004, and separated from the main Regency, Solok Regency. As a new administrative area, South Solok has 7 sub-districts consisting of Koto Parik Gadang Diateh (KPGD), Kecamatan Sungai Pagu, Kecamatan Alam Pauah Duo, Kecamatan Sangir Balai Janggo, Kecamatan Sangir Batang Hari, Kecamatan Sangir Jujuan, dan Kecamatan Sangir. Alam Surambi Sungai Pagu as a cultural area covers three sub-districts. They are Koto Parik Gadang Diateh, Kecamatan Sungai Pagu, and Kecamatan Alam Pauah Duo.

Gandang sarunai is a traditional art of the Alam Surambi Sungai Pagu community. Music terminology is used to refer to 'gandang sarunai art' as 'gandang sarunai music' because aspects of music are attached to the art. At this time, in the presentation of gandang sarunai music, there is a musical instrument: one gandang, one sarunai, one aguang, and one set of talempong pacik (two talempong as anak, two talempung as a dasar, and two talempong as paningkah. This instrumentation of gandang sarunai music is currently presented in the event of maarak anak daro jo marapulai (bridal procession) from the father family's house to the bride's house where the party is held, or it is held in the batagak pangulu procession (the inauguration of the title of new leader). While in the days of the kings of the past, instrumentation in the presentation of gandang sarunai music did not use talempong. It was usually presented on the front side of the king's throne or front side of the palaminan set when an event was held.

The focus of explanation this article is on changing the form of gandang sarunai music presentation in the socio-cultural activities of Alam Surambi Sungai Pagu community as well as what factors causing gandang sarunai music to remain sustainable in these socio-cultural activities.

To find out the musical concepts contained in gandang sarunai music culture and how it relates to these cultural activities, in the discussion, ethnomusicology concepts will be used, including what Malm said in Marzam [4] that, "... music is its meaningfulness to the culture. Music is used throughout .... life to teach him what he must know about his culture, about his place in it, and about its place in the world of nature and supernature ".

Talking about the musical concept of a society, in the end, it cannot be separated from the music problems technically. For this reason, the discussion of gandang sarunai in a musically will use general musicological procedures.

In relatian with the form of presentation, the form in Kamus Besar Bahasa Indonesia is the form that are displayed (http://kamusbahasaindonesia.org/b form accessed on 9 April 2016). What is meant by the presentation in http://kamusbahasaindonesia.org/bentuk (accessed April 9, 2016) is the appearance arrangement, in this case a physical form that shows a musical performance, which has been arranged sequentially to provide satisfying results for connoisseurs or the audience. According to Poerwadarminta, the form contains the meaning of being displayed. Presentation is the performance of the show from beginning to end [5]. Presentation can also be interpreted as a spectacle according to the appearance or appearance of a presentation [6]

In responding to the implications of naturally occurring changes of philosophers and great historians such as Arnold Toynbee and Spengler in Nur Mazidah [7], it is recommended that "... to deal with increasingly complex, widespread and profound problems, the development of new values, views and attitudes new, new ways and institutions are required."

Changes that occur in gandang sarunai music culture are discussed based on the elements of innovation in the culture itself. In this case, seeing changes in a culture is not only based on the direct influence of elements of foreign culture, but within the cultural context itself, there is renewal. Keammer in [4] states:

An important question concerning music change is how individual behavior that is subject to social pressures can still lead to new sociocultural norms. Examining these 
Authors, title

processes of change can substantially increase the range of explanations offered for present forms of music activity.

To maintain its existence and continuity in the life of modern society today, it is necessary to see what elements should be maintained. In addition, it is necessary to make changes or new forms need to be created based on the culture of the people who own the music.

Changes can occur due to the desires of the community groups or by the wishes of individuals in the cultural support community groups. Soedarsono in Mintargo [8] stated that the theory of social change put forward by Robert E. Park by following Spencer and Durkheim's view that social changes that occur in art are also due to changes in society in accordance with the conditions at that time.

In addition, Robert Chin and Kanneth D. Benne in Warren G. Bennis, et al. (ed.)[13] also stated that, "Change will occur only because the people involved can be moved by their hearts to change their normative orientation to the old patterns and develop a commitment to new patterns."

Some of the thinking concepts of experts that have been described above will be used as a basis for analyzing and interpreting the phenomenon of gandang sarunai music culture that grows, lives, and develops in the current Surambi Sungai Pagu community.

\section{Material \& Methodology}

The source of writing this article is the result of research by Marzam and Esy Maestro (2016) with the title "Continuity and Change of Music in Gandang Sarunai in the Life of Alam Surambi Sungai Pagu Society, Solok Regency."

This research belongs to qualitative research using descriptive, analytical and interpretive methods. Qualitative research is a type of research that intends to understand the phenomenon of what is experienced by the subject of research. It can be behavior, perceptions, actions, etc. holistically, and by means of descriptions in the form of words and languages, in a special natural context and with utilizing various natural methods [9]. In addition, in viewing and processing data using an ethnomusicological approach, the ethnomusicology approach is utilized. As what stated by Nettl in Irawati [10] explaining the three spheres of ethnomusicology studies including non-literate music, oriental music (oriental high culture) and folk music which are divided into several chapters such as musical composition themes, styles musicals, instruments, music in culture with historical and geographical approaches, and music in culture in context and communication. This provides an overview of what an ethnomusicologist must do in conducting traditional music research which is closely related to all aspects of the life of the supporting community. Ethnomusicological analysis is carried out to understand the form of music and musical content in gandang sarunai music. For this reason, an understanding of the cultural context is needed first. Nettl in Marzam [4] said, ... that music can be understood through a cultural context. Data was collected through literature study, interviews, and documentation. Interviews were conducted both formally and informally. During the interview, recording was done with a tape recorder. Besides that, it was also recorded and photographed.

To obtain the results of the study, all data collected were then processed, especially those relating to the problems studied. In the processing of the data, the logical mindset as intended by Muhadjir including: ... a contextual mindset ... is a mindset that emphasizes the present, current conditions or situations; ... interpretive mindset ... capturing behind the sensual or superficial. They were interpreted to find the explicit meaning [11]. Furthermore, the data processing was supported by the literature materials selected. Then, to get general arguments from the data processed, the inductive method was used which was studying a common symptom whose is known and believed to get a conclusion or new knowledge which is more specific. 
Authors, title

\section{Results and Discussion}

\subsection{Kontinuitas dan Perubahan}

Continuity or and change are unity that can not be separated when we see the life of music in the socio-cultural activities of a society. Changes that occur in musical performances basically occur and are carried out by the community of the owner in order to maintain the existence of the music in their social and cultural activities. Many factors that affect a change must occur or be performed in a musical performance. They can be got within their own community, It can also be influenced by cultural factors (music) that come from outside the community that owns the music. As explained by Marzam [4]," Seeing a change in a culture is not only based on the direct influence of elements of foreign culture, but also in the context of culture itself changes occur."

Gandang Sarunai music as one of the supporting elements in organizing the traditional events of the Surambi Sungai Pagu people has undergone significant changes in maintaining its continuity.

In the past, gandang sarunai music was one type of art presented in the holding of the Raja Alam Surambi Sungai Pagu traditional ceremonies. That is the importance of the existence of the music so that in organizing the traditional ceremony of the coronation of Raja Alam, the music of gandang sarunai was placed on the aisle at the front of the king's throne. According to Yasrial Katik Lembang Batuah (interview 12 October 2016) in Esy Maestro; Marzam [3], the performance of gandang sarunai music in the coronation ceremony of Raja Alam, the presentation of gandang nobat and the gandang puluik-puluik repertoire are symbolic or "hit hammer" that the new king is officially in power. Likewise, in other traditional ceremonies in the royal family or relatives of the royal family, gandang sarunai music is always presented as in the event of death, birth, traditional ceremonies taking baths, traditional wedding ceremonies, and so on.

At that time, there were only two kinds of gandang sarunai music devices. The first was gandang sarunai musical instrument consisting of two gandang, gandang jantan and gandang batino and one sarunai instrument. The econd one was gandang sarunai musical instrument consisting of gandang jantan, gandang batino, sarunai, and one agueng instrument. However, the gandang sarunai musical instrument on the second item is very rarely used because the gandang sarunai musical instrument that uses the agueng instrument is only used in traditional ceremonies held by the royal family and for the benefit of the king. For the traditional ceremony of level alek bakajo (alek nagari) and traditional ceremonies of the level of alek biaso (traditional ceremonies held by community members), agueng instruments should not be used. The provision is based on the customary rules that agueng may only be served during traditional ceremonies within the royal family, including: in the traditional ceremony of the coronation of the Raja Alam, the death ceremony of the royal family, the traditional ceremony of the royal family marriage (Yasrial Katik Lembang Batuah, interview 12 October 2016).

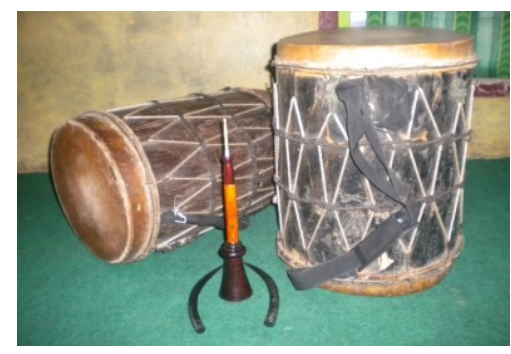

Picture 1

Gandang Sarunai music instrumentation consists of two gandang (gandang jantan and gandang batino), sarunai, and horns of gandang

(Source: Marzam Documentation in 2016) 


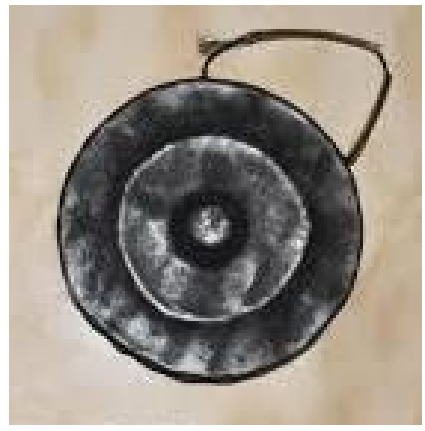

Picture 2

Aguang

(Sources: https://www.google.co.id/search?aguang+minang, accessed on October 17, 2016)

\subsection{Gandang Sarunai Music Show}

There are two changes occuring to gandang sarunai music performances. First, it is from the aspect of the venue. The second is from the aspect of instrumentation. Gandang Sarunai music performances in the past were held in rumah gadang (traditional house). During the coronation ceremony of Raja Alam, according to Yasrial Katik Lembang Batuah (interviewed on October $12^{\text {th }}$ 2016), the music venue for gandang sarunai was beside the front of the palaminan (King's throne). In other traditional ceremonies, gandang sarunai music is always served in the rumah gadang.

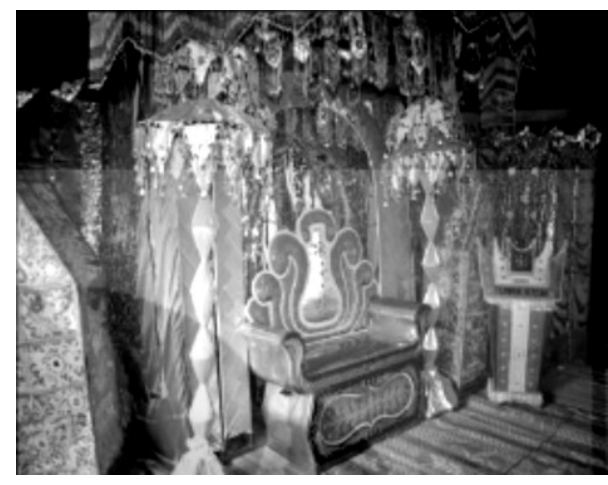

Picture 3

Palaminan (Singgasana) Raja Alam Surambi Sungai Pagu

Source: Yasrial Katik Lembang Batuah (Repro, Marzam 2016)

Nowadays, gandang sarunai music is more often performed in traditional community ceremonies, while traditional ceremonies performed by the royal family have rarely been held. After the era of independence, Raja Alam Surambi Sungai Pagu was no longer the Head of Government on Sungai Pagu. The position of the King has changed functions only to be a leader for his people. At that time until 2004 Alam Surambi Sungai Pagu was in the Sungai Pagu District, Solok Regency. In 2004, Solok Selatan District was formed as one of the new autonomous regions in Indonesia based on Law No. 38/2003 becoming effective from January 7, 2004, and was separated from the parent district, namely Solok Regency [12] Accessed 5-11-2016.

One of the socio-cultural activities of the people of Alam Surambi Sungai Pagu, which currently still presents gandang sarunai music, is at the wedding ceremony. There are customary stages of activities that must be passed before arriving at the wedding party, including 1) applying 
Authors, title

stage which is called the maantanan siriah from the male family to the female family; 2) the preparatory stage called manduduakan urang (family consultation in one tribe / people); 3) the implementation stage which consists of: a) Maantanan bali (seserahan), b) marriage contract with a manjapuik marapulai procession by urang sumando awaited by the bridegroom (marapulai) namely niniak mamak and urang sumando and both parents of the groom, c) prayers held at the bride's house (anak daro), and d) manjalang that is the family of the bride to take the bride to the groom's family home with a family consisting of anak pisang dan sumandan with gulai, rendang, and do not forget to bring snacks made from glutinous rice and bananas which, limpiang dan panyaram. The women's family at the house of the male family prayed together asking Allah SWT so that the two brides would live happily, harmoniously, peacefully and become a family which is syakinah, mawaddah and warrohmah.

The stages of the wedding party begin with manjapuik marapulai (picking up the bridegroom). The activity done by Mamak of the bride and was handed over to Urang Sumando. After arriving at the house of anak daro's child, Urang sumando of the wife's family waits for the marapulai with siriah in a carano in the yard before starting to go up to his wife's house. Thus, datang bajapuik, tibo bananti custom is clear.

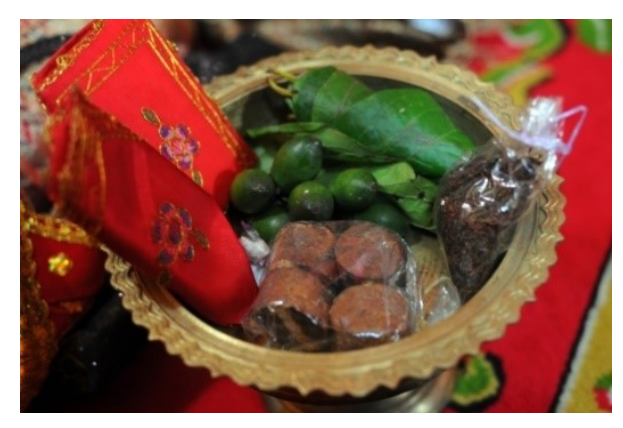

Picture 3

The symbol of greatness in accepting the marapulai and his family in the house of the anal daro. In adat, it is called datang bajapuik, tibo bananti.

(Source: https://www.google.co.id/search? Siriah + dalam + carano) accessed October $17^{\text {th }}, 2016$

Maanta marapulai (deliver the bridegroom) activity to anak daro's house is an activity where the marapulai starts the procession of asking blessing from parents to leave the house and will stay in his wife's house. When he is delivered by his family's urang sumando to the house of anak daro's child, the procession is a symbol that the marapulai is ready to be Urang Sumando in his wife's house.

Gandang Sarunai music performances are carried out in the Manjapuik procession and maanta marapulai. Anak daro jo marapulai begins to walk side by side to the child's family home from where the wedding party is held, accompanied by family and relatives from both parties. In the last two processions, gandang sarunai's music is presented.

There are two places and times for the show. First, it is on stage with a position in front of the bride and groom and served at night. The gandang sarunai music performance at that time aims to entertain the guests who come, especially the niniak mamak of the bride and groom. In having gandang sarunai music at night, instrumentation served only two gandang (gandang jantan and gandang batino) and one sarunai. Second, along the journey (procession) between 10 or 11 o'clock in the afternoon in manjapuik and maanta marapulai, the position of gandang sarunai's music in the event is in the middle of a group of processions. The foremost position of the procession is the bride accompanied by pasumandan, then followed by the bundo kanduang carrying the delivery, joined by music artists of Gandang Sarunai. In the last row, there were families and relatives who accompanied the bride to the party. 


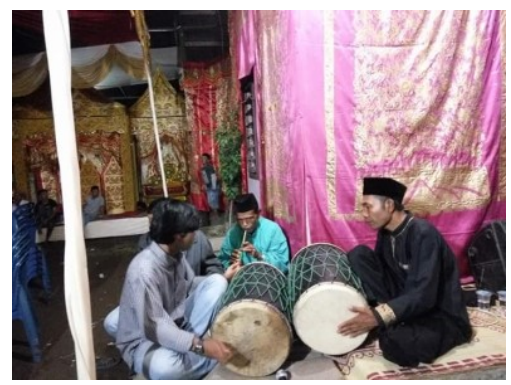

Picture 4

Gandang Sarunai music performances at night

(Source: Marzam Documentation 2016)

Holding gandang sarunai music in the procession of the bridal procession, from the aspect of the instrument, it consists of one gandang which is played while carrying by the artist, one sarunai, and a set of talempong which consist of anak, dasar, and paningkah. Each part consists of two talempong pieces played by three people with each part.

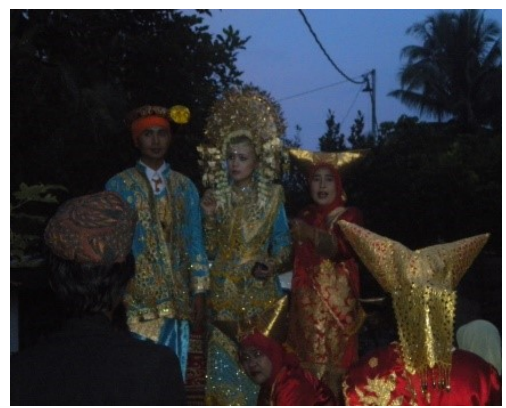

Picture 5

the front row of arak-arakan procession sided by pasumandan

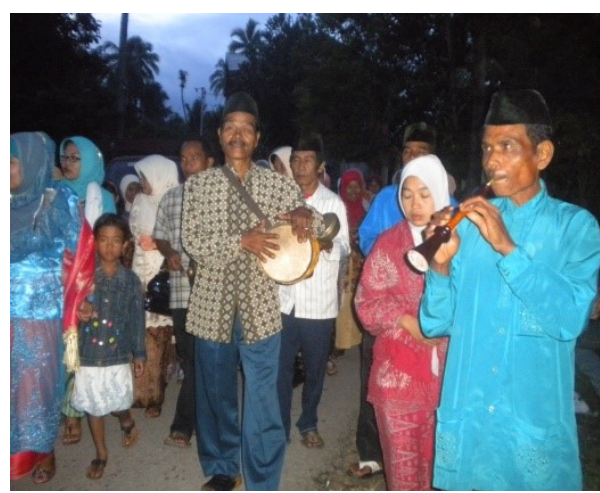

Picture 7

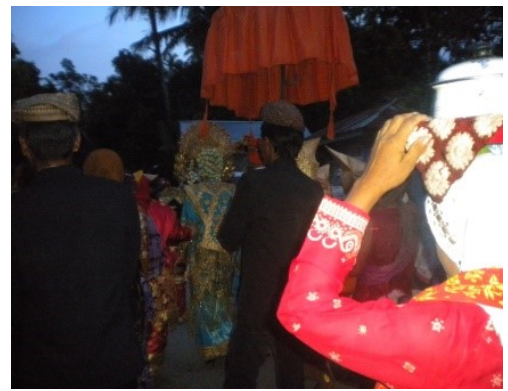

Picture 6

bundo kanduang bringing the hantaran is in the middle position

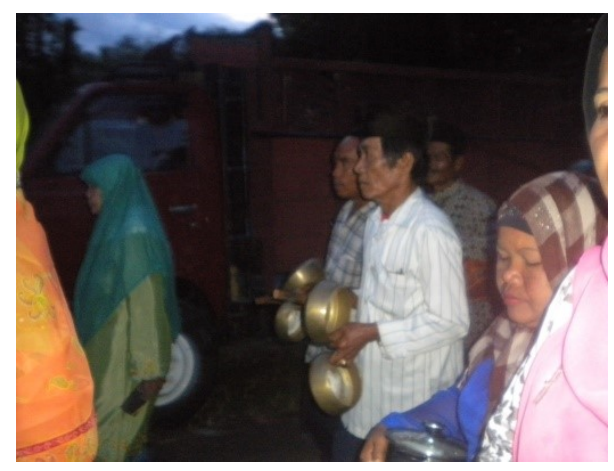

Picture 8

The position of the gandang sarunai music is in the middle between the families and relatives who accompanied the bridal procession (Source: Marzam Documentation in 2016)

Some changes have been made by gandang sarunai music artists with the aim of maintaining the existence or continuity of the music culture they have. The initiative emerged based on the unrest of music artists Gandang Sarunai over the marginalization of traditional music which has been the cultural identity of the natural music of Surambi Sungai Pagu. In addition, they made changes after contact with music culture that came from outside their musical life. As explained above, seeing a 
Authors, title

change in culture (in this case music) is not only based on the direct influence of elements of foreign culture, but also in the cultural context itself there is a desire to make changes.

\section{Conclusion}

The existence of traditional Minangkabau music today is experiencing significant degradation which can have an impact on the loss of music in the socio-cultural activities of the community. This also happens to gandang sarunai music. Gandang Sarunai music which has been the identity and pride of Alam Surambi Sungai Pagu community has been increasingly pushed into the presence of modern music that some people have begun to use in organizing their socio-cultural activities. However, there are things that cannot be replaced by the presence of modern music. In the customary wedding party of the Alam Surambi Sungai Pagu community, there are manjapuik processions and maanta marapulai which do not allow the presence of modern music in these activities. That space is the one that is still possible to be filled with traditional music performances (in this case gandang sarunai music). By making slight changes in terms of instrumentation and venue, the continuity of gandang sarunai music is maintained in the social cultural activities of the Alam Surambi Sungai Pagu community.

Acknowledgement. This research is fully supported by Affiliation Research Grant.

\section{References}

[1] https://id.wikipedia.org/wiki/Alam_Surambi_Sungai_Pagu, "Alam Surambi Sungai Pagu.” [Online]. Available: https://id.wikipedia.org/wiki/Alam_Surambi_Sungai_Pagu.

[2] Marzam, "Gandang Sarunai: Musik Tradisional Masyarakat Sungai Pagu Kabupaten Solok Selatan Sumatera Barat," Humanus, vol. VII, no. 2, pp. 159-168, 2005.

[3] Maestro Esy; Marzam, "The Concept and Meaning of Gandang Sarunai Music as Reflected Through The Social and Cultural Activities of The Alam Surambi Sungai Pagu Community of South Solok District, West Sumatra," in Advances in Social Science, Education and Humanities Research (ASSEHR), Sixth International Conference on Languages and Arts (ICLA), 2018, pp. 263-267.

[4] Marzam, Basirompak: Transformasi Aktivitas Ritual Magis Menuju Seni Pertunjukan, Pertama. Yogyakarta: KEPEL Press, 2002.

[5] W. J. S. Poerwadarminta, "Kamus Umum Bahasa Indonesia Edisi Ketiga (diolah kembali oleh Pusat Bahasa Departemen Pendidikan Nasional)," Jakarta: Balai Pustaka, 2003.

[6] W. Lestari, “Teknologi Rias Panggung,” Hand Out IKIP Semarang Press, 1993.

[7] N. Mazidah, "Relijiusitas dan Perubahan Sosial dalam Masyarakat Industri," J. Sosiol. Islam, vol. 1, no. 1, pp. 17-34, 2011.

[8] V. Mintargo, Wisnu; Soedarsono, RM.; Ganap, "Fungsi Lagu Perjuangan Sebagai Pendidikan Karekter Bangsa," KAWISTARA, vol. 4, no. 3, pp. 225-330, 2014.

[9] M. P. K. Moleong and J. M.-M. P. Kualitatif, "Remaja Rosdakarya.” Bandung, 2009.

[10] Eli Irawati, "Makna Simbolik Pertunjukan Kelentang dalam Upacara Belian Sentiu Suku Dayak Benuaq Desa Tanjung Isuy, Kutai Barat Kalimantan Timur," J. Kaji. Seni, vol. 01, no. 01,pp. 60-73, 2014.

[11] M. Noeng, "Metode Penelitian Kualitatif Edisi III.” Rake Sarasin, Yogyakarta, 1996.

[12] http://ditjenpdt.kemendesa.go.id/potensi/district/71-kabupaten-solok-selatan, "Kabupaten Solok Selatan." [Online]. Available: http://ditjenpdt.kemendesa.go.id/potensi/district/71kabupaten-solok-selatan. 
Authors, title

[13] Bennis, Warren G.; Kenneth D. Benne; Robert D. Chin (ed.) Merencanakan Perubahan. Terjemahan Wilhelmus W. Bakowatun dan Bosco Carvalo. Intermedia. Jakarta 1990. 